\title{
Glucose Mediated Regulation of Beta Cell Proliferation
}

\author{
Adolfo Garcia-Ocaña* and Laura C. Alonso
}

Division of Endocrinology, University of Pittsburgh, Pittsburgh, PA 15261, USA

\begin{abstract}
The pancreatic beta cell, as the sole source of circulating insulin, is indispensible for normal glucose metabolism. All forms of diabetes are characterized by insufficient insulin to meet metabolic needs, and inadequate beta cell mass is present in most forms of diabetes. Beta cell regenerative therapies provide one potential avenue for the prevention or cure of diabetes. Study of the pathways and mechanisms involved in endogenous beta cell proliferation can provide important clues to how regeneration occurs. Glucose is one important regulator of beta cell replication. Here we review the published literature investigating the effect of glucose on beta cell proliferation, and then describe the data supporting various known mechanisms of action. First, in vitro studies on fetal and adult beta cells from rodents and humans are reviewed. Next, we review evidence that circulating blood glucose regulates beta cell proliferation in living animals. These studies encompass a variety of in vivo models, including dietary manipulation, partial pancreatectomy, intravenous infusion of glucose, islet transplantation, and studies on diabetic hyperglycemia. Finally, mechanistic studies, both in vitro and in vivo, point to several different mitogenic pathways activated by glucose. Especially prominent are insulin signaling pathway members, glucose metabolism, and glucose impact on signaling by other growth factors. Multiple unanswered questions remain, and are highlighted throughout. With today's technologies we can now address questions first raised in the early 1900s, and hopefully develop new approaches to assuage the devastation of clinical diabetes.
\end{abstract}

Keywords: Glucose, pancreatic beta cell, proliferation, insulin, diabetes.

\section{INTRODUCTION}

Historically, beta cells of adult animals were thought to be largely post-mitotic. This dogma persisted for many years, in part because techniques for studying replication in whole animals were not as easy to apply as they are today, and in part because the actual replication rate in steady-state, unstressed adult animals is indeed quite low [1]. However, in times of increased metabolic need, the rodent endocrine pancreas is an organ with impressive plasticity. Concomitant with an increase in insulin requirement in the body, there is an enhancement in beta cell mass. Conversely, when insulin requirements are lowered, a prompt reduction of beta cell mass takes place. This increase in islet mass has been observed in pregnancy, partial pancreatectomy, and obesityinduced insulin resistance [2-5]. The reverse scenario with reduction of islet mass occurs following parturition, glucose level normalization and sustained improved insulin sensitivity. Studies show that similar compensatory mechanisms may be active in human conditions characterized by increased insulin requirements $[6,7]$. Although the origin of the new beta cells in these situations remains controversial and seems to depend on the pathophysiological model under study, beta cell proliferation is widely accepted to play a critical role in all of them. Thus, during normal physiologic and pathologic metabolic alterations, the rate of beta cell proliferation changes over time depending on the metabolic

*Address correspondence to this author at the University of Pittsburgh, Division of Endocrinology and Metabolism, 200 Lothrop Street, BSTE1140, Pittsburgh, PA 15261, USA; Tel: 412-648-3289; Fax: 412-6483290; E-mail: ocana@pitt.edu requirements and the local environment in and around the beta cell.

Intuitively, blood glucose level is a logical primary actor influencing beta cell proliferation in situations of beta cell compensation due to increased metabolic demand. An important effect of insulin is to increase flux of glucose out of the bloodstream and into tissues such as liver, muscle and fat. As glucose is the primary regulator of insulin secretion, the beta cell is exquisitely sensitive to glucose concentrations [8]. Elevated glucose concentration in the blood is an early indicator of insulin insufficiency. Therefore, elevated glucose seems a reasonable candidate to mediate need-driven beta cell expansion.

In this review we will first examine the in vitro evidence showing the mitogenic effects of glucose on rodent and human pancreatic beta cells. Next, we will describe in vivo studies that have demonstrated the relevance of glucose as a physiological regulator of beta cell replication. Finally, although the mechanisms involved in beta cell compensation to glycemic stress in vivo remain largely unidentified, we will explore the mechanistic insight provided by in vitro experimentation.

\section{EVIDENCE THAT GLUCOSE INDUCES BETA CELL PROLIFERATION IN VITRO}

From the earliest work in culturing beta cells, glucose was known to be an important requirement for optimal beta cell growth. Many culture model systems, including fetal and neonatal beta cells [9], continuous insulinoma cell lines [10, 11], and primary islets [12-14] have all demonstrated a growth advantage in response to glucose. Thus, cultured beta 
cells have been shown in multiple different laboratories, in culture systems ranging from continuous insulinoma cell lines to primary freshly isolated islets, to proliferate in response to elevated glucose.

\section{Rodent Beta Cells}

In the early eighties, Swenne and colleagues were pioneers in analyzing the effect of glucose on DNA synthesis in rat beta cells $[9,13,15-17]$. Islets of fetal, neonatal, and adult rats were isolated and cultured at different glucose concentrations and DNA synthesis rates were calculated by pulse labeling with ${ }^{3} \mathrm{H}$-thymidine. When the glucose concentration of the culture medium was raised from 2.7 to $16.7 \mathrm{mM}$ the rate of beta cell proliferation increased 2.5-fold in all age groups, but there was no further increase in proliferation at $33.3 \mathrm{mM}$. Although the fold increase was equal, the rate of beta cell replication at each of the glucose concentrations decreased with increasing donor age. These results were the first to demonstrate that normal rodent beta cells replicate in response to glucose and that aging decreases the capacity of beta cells to proliferate in absolute terms in the presence of high glucose concentrations $(16.7 \mathrm{mM})$. These data were also the first to suggest an interesting parallel to the development of type 2 diabetes in humans, in which an inherited low capacity for beta cell regeneration in the presence of increasing blood glucose may participate in the development of the disease.

Other research groups confirmed these initial results by labeling fetal and adult rat islets in vitro using a thymidine analog that cannot be reutilized by the cell, 5-bromo-2deoxyuridine (BrdU) or by fluorescence activated cell sorting (FACS) analysis of dispersed adult rat islet cells [18, 19]. Furthermore, the proliferative effects of glucose in adult beta cells have also been observed in mouse beta cells as well as several insulinoma beta cell lines [10, 11, 18, 20-22].

However, the involvement of glucose in fetal beta cell proliferation seems more controversial. In contrast to the studies mentioned above, recent studies by the Scharfmann group have shown that $10 \mathrm{mM}$ glucose increases 20 -fold the area of insulin-positive cells in embryonic pancreases in culture (compared with $0 \mathrm{mM}$ ) without increasing beta cell proliferation, but rather enhancing the differentiation of early progenitors into beta cells by regulating the transition between Ngn3 and NeuroD [23]. However, basal (low glucose) beta cell proliferation was not measured in this study. These studies are important since they may uncover a role for glucose in beta cell allotment in intrauterine growth retardation or maternal gestational diabetes, with possible repercussions on glucose homeostasis and beta cell mass in adulthood.

\section{Human Beta Cells}

Encouraged by the mitogenic effects of glucose in rodent beta cells, several groups have analyzed the dose- and timedependent effects of glucose on human beta cell replication in vitro. Tyrberg et al. reported in 1996 that the human beta cell labeling index (LI; i.e. \% of labeled beta-cells over total number of beta-cells) was increased when islets were cultured for $48 \mathrm{~h}$ at $5.6 \mathrm{mM}$ glucose compared with $2.8 \mathrm{mM}$ glucose. Interestingly, and in contrast to the results observed in adult rat islets, $11 \mathrm{mM}$ glucose failed to further increase beta-cell proliferation [24]. More recently, the Donath group has performed a more detailed analysis of the temporal effects of glucose in human beta cells employing the cell cycle progression marker, Ki67, and insulin staining as means to detect beta cell proliferation in cultured human islets $[14,25,26]$. Short-term (1-3 days) exposure of cultured human islets to $33.3 \mathrm{mM}$ glucose increased the number of proliferating (Ki67-positive) beta cells, whereas prolonged ( $>4$-day) exposure resulted in an inhibition of proliferation, relative to islets at $5.5 \mathrm{mM}$ glucose. This decrease in human beta cell proliferation induced by chronic incubation with glucose was independent of the age of the islet donor. On the other hand, $33 \mathrm{mM}$ glucose increased human beta cell apoptosis after the first day of incubation. These studies suggest that the reduced glucose-mediated proliferative response coupled with increased beta cell death in response to extremely high-glucose concentrations in vitro might represent a similar sequence of events observed in vivo during the evolution of diabetes. Unfortunately, in these later studies, lower concentrations of glucose representing milder hyperglycemia that could potentially trigger beta cell compensatory expansion were not used.

\section{EVIDENCE THAT GLUCOSE INDUCES BETA CELL PROLIFERATION IN VIVO}

It is well documented that pancreatic beta cells perform quite differently in a petri dish than they do when embedded in the living organism, although the reasons for this remain speculative [8]. Thus, for the purposes of developing treatments for diabetes, investigating the signals that drive beta cell replication must be performed or confirmed in vivo. Several different in vivo approaches have suggested that glucose may regulate beta cell replication. Manipulation of food macronutrients has been used to raise the blood glucose. Partial pancreatectomy, or surgical removal of a portion of the pancreas, induces hyperglycemia to a variable degree. Glucose infusion is a more direct approach to raising the blood glucose, not subject to the myriad local changes in the pancreas caused by surgery and healing. Infusion protocols, however, are technically challenging and require specialized equipment and expertise. Islet cell transplant, while also challenging, is a flexible technique, allowing study of islets from different species including human, and pre-transplant manipulation of islets as well. The challenge in using transplantation to study the role of glucose in beta cell replication is developing tools to allow titration of circulating host blood glucose. Mouse genetic models have also been used to address the question of glucose as a driver of beta cell replication. Finally, diabetes itself is characterized by hyperglycemia, and this has been used to investigate the role of glucose on beta cell replication. In this section we will review the data suggesting that glucose induces beta cell proliferation in vivo.

\section{Manipulation of Orally-Administered Macronutrients}

Oral administration of sucrose is a technically simple means to increase the metabolic load on the pancreas and, in some cases, increase blood glucose. Rats allowed ad libitum access to a sucrose-rich diet for thirty weeks [27] developed significant hyperglycemia $(8.1 \mathrm{mM}$ in sucrose-treated rats versus $6.6 \mathrm{mM}$ in controls), which correlated with a robust increase in beta cell mass (15 mg versus $6 \mathrm{mg}$ ) and a large 
$6.8 \mathrm{x}$ increase in beta cell replication 30 weeks into the treatment $(0.27 \%$ versus $0.04 \%$ PCNA positive beta cells $)$. Similarly, feeding hamsters excessive sucrose via the drinking water caused a robust increase in beta cell replication [28]; however, blood glucose did not increase $(7.1 \mathrm{mM})$, and in this case the changes were attributed to sucrose-driven insulin resistance.

In Psammomys obesus, researchers independently manipulated the energy content of the diet and the blood glucose (using phlorizin), and found that beta cell replication increased dramatically after 2 and 5 days of high blood glucose (approximately $15 \mathrm{mM}$ and $20 \mathrm{mM}$, respectively) [29]. After 22 days of high blood glucose (approximately 21 $\mathrm{mM}$ ) beta cell replication was still elevated over baseline, although the rate declined from the high seen at 2-5 days. Lowering blood glucose with phlorizin (approximately 7 $\mathrm{mM}$ ) promptly reduced beta cell replication to baseline levels, suggesting that the beta cell replication was due to hyperglycemia.

\section{Recovery from Hypoglycemia}

In an interesting reverse experiment exploring the effects of hypoglycemia on islet morphology and function, female Wistar rats received continuous infusion of insulin via miniosmotic pump for six days [30]. During hypoglycemia (approximately $2 \mathrm{mM}$ glucose), beta cell replication was suppressed, and during the rebound hyperglycemia following pump removal (approximately $11 \mathrm{mM}$ ) beta cell replication increased. These data suggest that hyperglycemia stimulates beta cell replication, but also that hypoglycemia suppresses basal beta cell replication. Furthermore, this is one piece of evidence that insulin itself may not be the glucose-dependent driver of mitogenesis (see below), although peripherally administered insulin may not come close to reaching the intra-islet insulin concentration that occurs during normal beta cell insulin release.

\section{Pancreatectomy: Does Glucose Signaling Contribute to Beta Cell Regeneration?}

In rodents, partial pancreatectomy is a well characterized injury model of beta cell regeneration. The degree of postoperative hyperglycemia, if present, is dependent on the volume of pancreas removed [31-33]. A role for glucose in post-operative beta cell regeneration has been debated, largely due to the fact that a commonly used pancreatectomy procedure, $60 \%$ pancreatectomy, which leads to robust beta cell regeneration, does not lead to elevated circulating blood glucose [34]. Certainly, other signals besides glucose, such as local surgery-stimulated growth factors and cytokines, may contribute to beta cell regrowth. Hyperglycemia, however, may contribute to post-pancreatectomy regeneration; when drinking water was replaced with sucrose water post-operatively, blood glucose increased $(9.2 \mathrm{mM})$, and beta cell mass increased dramatically relative to pancreatectomy controls drinking untreated water $(8.3 \mathrm{mM})$ [35]. However, hyperglycemia after pancreatectomy has also been shown to negatively impact insulin secretion $[34,35]$.

Intriguingly, even in the setting of normoglycemia postpancreatectomy, glucose metabolism appears to be increased in the islet. One study found that glucose utilization increased and glucokinase activity doubled in islets four weeks after $60 \%$ pancreatectomy [34]. A follow-up study determined that glucose metabolism was markedly increased five days after pancreatectomy, with a tripling of glucose phosphorylation, a doubling of glucose usage, and a six-fold increase in glucose-6-phosphate metabolism through the pentose phosphate shunt [36]. At four weeks, these metabolic changes had mostly returned to normal. Beta cell replication correlated exactly with the changes in glucose metabolism, being highest at five days and essentially back to baseline by four weeks. In another related work, increased flux through the pyruvate carboxylase pathway after pancreatectomy in rats was found to be important for beta cell regeneration [37].

Therefore, in the $60 \%$ pancreatectomy model of beta cell regeneration, circulating blood glucose is not increased, but beta cell replication is robustly induced. Interestingly, increased flux through glucose metabolic pathways in the beta cell may represent an equivalent signal to hyperglycemia. Experiments such as these may give insight into downstream mechanisms of glucose signaling in beta cell regeneration.

\section{Glucose Infusion Models: Rat and Mouse}

Intravenous infusion of glucose is a direct method of increasing circulating blood glucose, without attendant changes due to surgery on the pancreas, or the endocrine/hormonal changes of obesity, diabetes, or pregnancy. As early as 1938, in a tour de force experiment starting with fashioning a catheter out of rubber tubing and devising a continuous pumping apparatus, continuous infusion of glucose into the external jugular vein of guinea pigs was reported to increase blood glucose slightly (approximately $5.6 \mathrm{mM}$ basal, $8.2 \mathrm{mM}$ during infusion), without glycosuria [38]. In these guinea pigs, they found an increase in islet tissue at four to five days of infusion, which was associated with mitotic figures in beta cells of larger islets at four and seven days. In another remarkable study, wild Argentine toads were captured and infused with glucose for five days, which resulted in hyperglycemia $(28 \mathrm{mM} v s$ $1.3 \mathrm{mM}$ ) and increased beta cell replication as measured by BrdU incorporation [39].

In the 1980s, the continuous glucose infusion experiment was resurrected and optimized as a tool to study regulators of beta cell regeneration [40]. In rats, glucose was infused through the jugular vein at a rate that resulted in severe hyperglycemia (approximately $23 \mathrm{mM}$ ) on the first day, but declined significantly on the second day (approximately 18 $\mathrm{mM})$, and normalized by the fourth day $(7.8 \mathrm{mM})$. Beta cell replication was analyzed by counting mitotic figures after a four hour colchicine arrest. After four days of infusion, beta cell replication increased five fold. Additionally, individual beta cell volume increased $50 \%$, and overall beta cell mass increased $50 \%$. These findings have been supported [41] and contested [42]. A longer glucose infusion study in rats, extending the infusion duration to six days, found that beta cell replication was decreased on day 1 , but increased by days 3-6; beta cell mass linearly increased with time [43]. Glucose infusion studies in which the duration of infusion was less than 72 hours have not reported an increase in beta cell replication [44-46]. The majority of rat glucose infusion studies have utilized infusion protocols that result in severe 
hyperglycemia on the first $1-2$ days $(>20 \mathrm{mM})$. One study infused a lower quantity of glucose, resulting in a subtle increase in blood glucose levels on days 1-2 (approximately $6.7 \mathrm{mM}$ ), with no hyperglycemia on days 3-4 (approximately $5.6 \mathrm{mM}$ ). Data from this experiment showed no glucoserelated increase in beta cell replication, but the blood glucose was only slightly elevated for two days, and the control rate of replication was high (5\% Ki67-positive beta cells), which may represent adolescence-related overall (and beta cell) growth [42].

Rat glucose infusion studies have been quite sophisticated, including combination interventions such as glucose infusion after streptozotocin $[45,46]$ or hypothalamic ablation [47], or in combination with euglycemic hyperinsulinemic clamps [41, 44, 46, 48]. Illuminating post-intervention analyses such as immunostaining [42], RNA quantification [41, 49], or immunoblot [42] have been performed. However, one of the most powerful tools to dissect mechanistic pathways, transgenic and knockout technology, is not widely developed in the rat. In order to apply the power of mouse genetics to the question of how glucose induces beta cell proliferation, we adapted the rat glucose infusion procedure for use in mice [50]. In mice, four day infusion of glucose results in mild persistent hyperglycemia $(7.6 \mathrm{mM} ; 25 \%$ increase over baseline) and hyperinsulinemia (125\% increase), and a large $(500 \%)$ increase in beta cell replication (Fig. 1). These data confirm, in a second rodent model, that hyperglycemia induces beta cell proliferation. Our model shows interesting differences with the rat glucose infusion work. In rats, the blood glucose surges to extremely high levels for 1-2 days, returning to normal by 96 hours. In mice, the blood glucose increase is quite moderate, but is sustained for as long as the infusion continues, up to four days. Infusion of greater quantities of glucose in the mouse, to attempt to achieve higher blood glucose, is not tolerated (personal observation). Plasma insulin levels in both mouse and rat increase greatly during the first 1-2 days, with subsequent return to nearbaseline levels by day 4 . In mice, no increase in beta cell size or mass was detected after four days of infusion, whereas both these parameters increase in rats infused with glucose.

Peripheral insulin resistance increases beta cell replication (e.g. [51]). It has been hypothesized that glucose infusion increases beta cell replication by increasing insulin resistance. However, studies do not support this hypothesis. In the rat, in a euglycemic clamp after four days of continuous glucose infusion, an increased glucose infusion rate was required to sustain the same blood glucose, suggesting increased insulin sensitivity [41]. In a different study protocol, cyclically infused glucose (four hours on, four hours off) did not alter insulin sensitivity [48]. Four day infusion of glucose in rats, clamping blood glucose at 9.4 $\mathrm{mM}$, required increasing glucose infusion rate to maintain the same degree of hyperglycemia, and insulin sensitivity was increased two hours after termination of the infusion [52]. In the mouse glucose infusion model, insulin resistance does not increase (personal communication, Dr. Christopher O'Donnell, University of Pittsburgh). Therefore, alterations in peripheral insulin sensitivity do not explain the increase in beta cell replication resulting from glucose infusion in the rodent, suggesting that glucose may be acting at the level of the beta cell.

\section{Beta Cell Transplant Models}

Islet transplantation is under intense investigation as a potential therapy for both type 1 and type 2 diabetes. Transplantation is also a useful model to study beta cell physiology, allowing experimental manipulation of the islet outside of its normal pancreatic environment, yet in an in vivo setting. Combining islet transplantation with chemical ablation of the endogenous beta cells allows independent control of beta cell mass and blood glucose. The islet transplantation technique has been applied to the question of whether glucose stimulates beta cell replication in vivo, in a transplant setting. In one early study, streptozotocin-diabetic mice received syngeneic islet transplants under the kidney capsule, of either an insufficient number of islets to achieve normoglycemia, or of a full replacement dose of islets [53]. The former mice remained severely hyperglycemic $(20 \mathrm{mM})$, whereas the latter were normoglycemic. Beta cell replication was increased in the hyperglycemic mice ten days after transplant, although beta cell graft mass progressively declined and the beta cell replication rate at 18 or 30 days was no longer elevated, suggesting graft failure due to severe hyperglycemia.

In a complicated rat experiment, involving 95\% pancreatectomy and/or islet transplantation in various combinations and sequences, it was noted that rats transplanted before pancreatectomy showed an increase in beta cell replication after pancreatectomy, in both the graft and the pancreas, whereas rats transplanted after pancreatectomy did not [4]. Blood glucose was elevated $(18.8 \mathrm{mM})$ in the latter group but not the former $(6.1 \mathrm{mM})$. It is not clear that these groups are comparable, however, since the duration of pancreatectomy-induced metabolic stress on the beta cell was 14 days in the former group but 28 days in the latter group, perhaps implicating a time-dependence of the beta cell replication response (see below).

Studies have confirmed the hyperglycemia-related increase in beta cell replication in islet grafts [54, 55]. Streptozotocin-diabetic mice received an insufficient mass of syngeneic islets to restore normoglycemia, either with or without insulin therapy to normalize blood glucose. Normoglycemic mice showed no increase in beta cell replication in the graft, whereas hyperglycemic $(25 \mathrm{mM})$ mice showed increased graft beta cell replication at 14 days after transplant but not at 60 days after transplant. This again confirms that severe hyperglycemia increases beta cell replication early, but the replication response is not sustained. A follow up study by this group again showed that glucose-related beta cell proliferation occurred at 14 days but was lost at 60 days. Interestingly, the glucose-induced replication that was lost after long term hyperglycemia was recoverable following a period of normoglycemia induced by a second islet transplant [56]. In another follow up study, with a shorter time course, graft beta cell replication was increased after 10 days of hyperglycemia $(24 \mathrm{mM})$ but not after 3 or 30 days; replication was suppressed by insulin therapy [57]. In one final mouse study, a carefully performed double transplant protocol was developed, in which streptozotocin-diabetic mice received a therapeutic transplant in the epididymal fat pad, then a minimal transplant (62 islet equivalents) under the kidney capsule [58]. When the therapeutic graft was removed, the mice developed 
A.

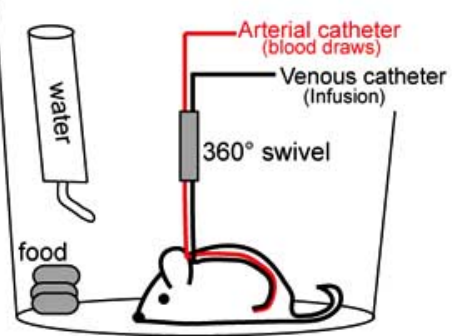

B.

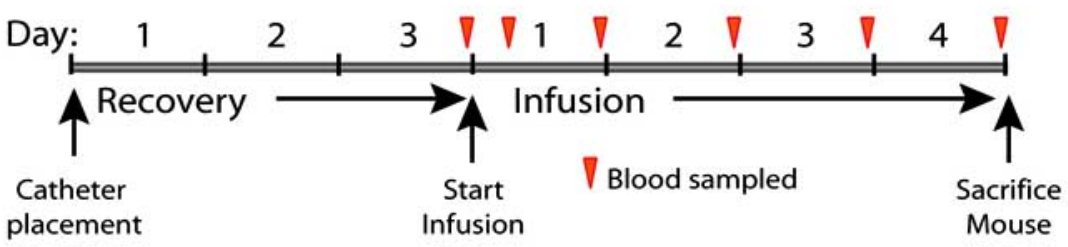

C.

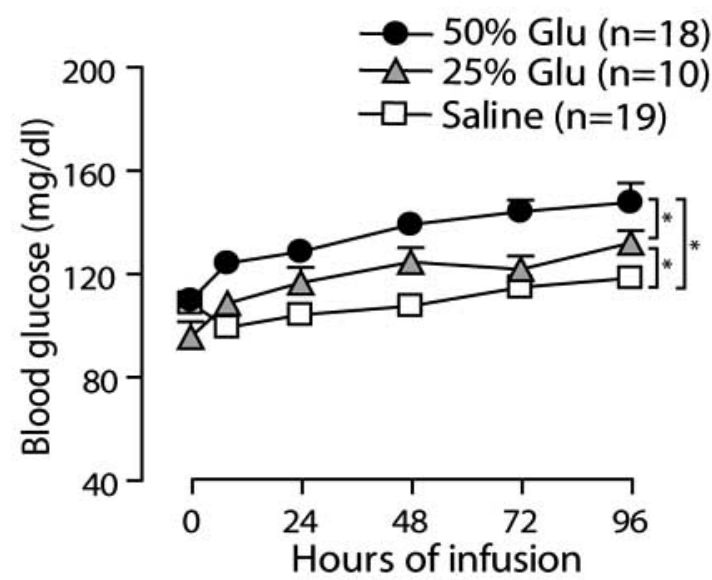

E.

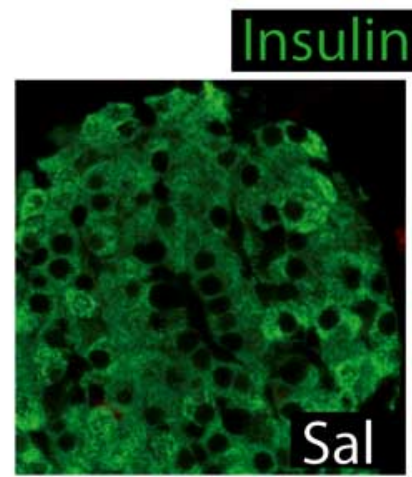

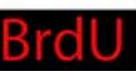

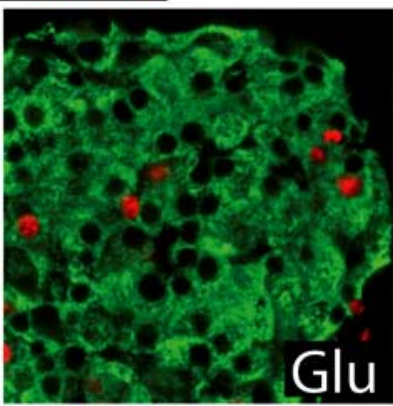

D.

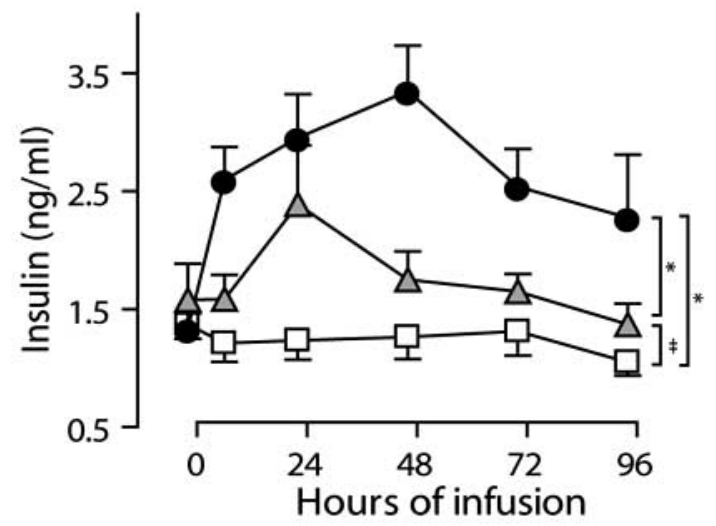

F.

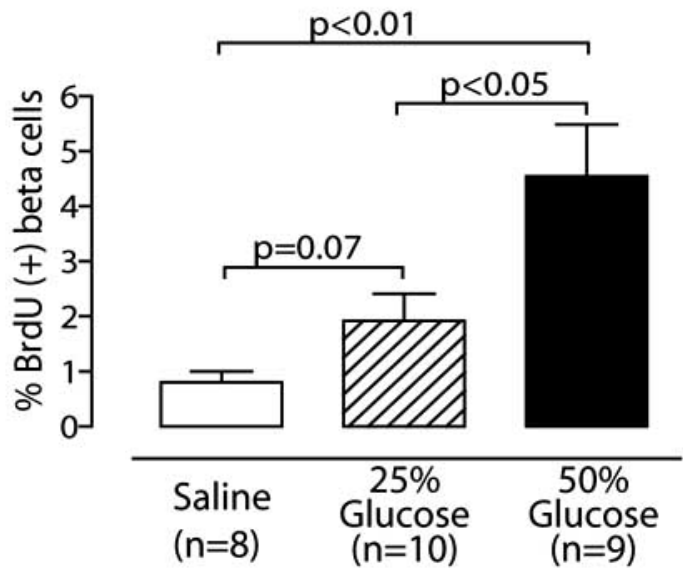

Fig. (1). Glucose infusion induces beta cell replication in vivo in mice. Mice with catheters in the femoral artery and vein are individually housed with ad libitum access to food and water (A). After a three day recovery period, four day infusion with saline, $25 \%$ glucose, or $50 \%$ glucose (B), results in moderate, sustained hyperglycemia (C) and hyperinsulinemia (D). Glucose infusion causes a dose-dependent increase in replication (E-F). Copyright 2007 American Diabetes Association, from [50], modified with permission.

hyperglycemia $(13.5 \mathrm{mM})$; beta cell replication in the minimal graft increased fifteen-fold, as measured by both BrdU incorporation and Ki67 immunodetection. In contradiction to much published literature, they found similar proliferation rates in islet grafts from young (3 months) and old (20-24 months) mice.

Human islets transplanted into immune-compromised mice have been evaluated for glucose-induced beta cell replication. In one study, human beta cells exposed to severe hyperglycemia $(24 \mathrm{mM})$ had a similar rate of replication to those in normoglycemic conditions, fourteen days after transplant [24]. In a different study, human islets were transplanted into $\mathrm{Ob} / \mathrm{Ob}$ mice with immunosuppression. Human beta cell replication doubled in the context of $\mathrm{Ob} / \mathrm{Ob}$ relative to lean controls [59]. Although glucose was mildly increased in the $\mathrm{Ob} / \mathrm{Ob}(9 \mathrm{mM}$ vs $6 \mathrm{mM})$, other obesityrelated differences (body mass, hyperinsulinemia, hyperlipidemia, inflammatory changes, etc) could also have induced beta cell replication. 
In summary, islet transplant experiments confirm a role for hyperglycemia in stimulating beta cell proliferation, and suggest that transplanted islets respond similarly to islets in their usual pancreatic environment. Glucose-stimulated beta cell replication in these experiments was time-dependent, with replication response declining after several weeks' exposure to hyperglycemia, but the capacity of beta cells to mount a proliferative response to hyperglycemia $(25 \mathrm{mM})$ was restored after a period of normoglycemia.

\section{Hyperglycemia of Diabetes}

One could argue that determining whether beta cells replicate during the hyperglycemia associated with the onset of diabetes is the most important question, because this gives insight into the endogenous beta cell regeneration process that is the therapeutic goal. If regeneration is ongoing, but overwhelmed by autoimmune destruction (type 1) or insulin requirement and toxic environment (type 2), regenerative therapies are more likely to be effective than if a de novo beta cell regeneration process has to be created.

One group has looked carefully at beta cell proliferation rates in early murine autoimmune diabetes [60]. Across several different genetic backgrounds, using multiple models of diabetes and modulation of blood glucose using insulin pellets and islet transplants, they found a direct correlation between beta cell proliferation rate and blood glucose across a wide range of glucose concentrations (6-22 mM).

In many rodent models of type 2 diabetes, beta cell replication has been shown to be increased; this increase has been attributed to insulin resistance. A role for glucose or glucose signaling has never been demonstrated, and in some cases, the onset of beta cell proliferation occurs prior to the onset of frank hyperglycemia [61, 62]. However, given the exquisite sensitivity of the beta cell for minor changes in blood glucose, potential unexamined effects of intermittent postprandial glucose excursion, and the stress-related increase in blood glucose inherent in various methods of sample collection (tail snip, retro-orbital bleed, submandibular bleed), it remains possible that a role for glucose in this process has been missed.

Evidence for glucose-driven beta cell proliferation in diabetic humans is sparse [63]. One study found increased beta cell replication and apoptosis in a man requiring pancreatectomy early in the course of type 1 diabetes [64]. Another study found ongoing beta cell apoptosis in people with longstanding type 1 diabetes, which indirectly suggests ongoing replication [65]. Neither study directly associates hyperglycemia with these findings. Pancreatectomy in humans leads to diabetes, without overt evidence for any regeneration [66, 67]. Clearly, more investigation is warranted to determine whether glucose regulates human beta cell replication, and if so, what mechanisms are involved.

\section{MECHANISTIC INSIGHTS INTO HOW GLUCOSE INDUCES BETA CELL PROLIFERATION}

Glucose influences extracellular mitogens, internal receptor-related signaling, downstream signaling pathways, pro- or anti-mitogenic transcription factors, and the cell cycle (Fig. 2). However, whether these glucose-mediated alterations in the intracellular network are involved in glucose-induced beta cell proliferation in vivo awaits further studies. The generation of a chronic glucose infusion model in mice (Fig. 1) and the presence of myriad mouse genetic models in which genes encoding intracellular molecules have been altered specifically in beta cells will provide new clues to glucose-regulated beta cell proliferation and expansion in vivo in the near future. The elucidation of glucose-mediated growth-regulating pathways may give rise to novel pharmacological means of expanding the remaining endogenous beta cell population in diabetes.

\section{Insulin Signaling Pathway}

The most obvious potentially mitogenic effect of glucose is the local secretion of insulin, a robust mitogen for some cell types. Insulin signaling promotes beta cell replication $[68,69]$. Knockout of the insulin receptor (IR) in beta cells results in normal beta cell mass, at least initially, suggesting that insulin is not essential for beta cell proliferation [70]. However, in vitro studies have shown that glucose modulates well-documented intracellular signaling molecules of the insulin signaling pathway including insulin receptor substrate 2 (IRS2), phosphatidylinositol 3'-kinase (PI3K) $[11,71,72]$, protein kinase $\mathrm{B}(\mathrm{PKB})$, glycogen synthase kinase-3 (GSK-3), extracellular signal-regulated kinase (ERK) $1 / 2$, and mammalian target of rapamycin (mTOR) [11, 20,71-78]. Interestingly, the major effects of glucose on beta cells, activation of PI3K, PKB, GSK3, ERK, S6K and mTOR, are also the principal downstream effects of activation of IRS2.

IRS2 is a central factor that mediates signals from several known beta cell mitogens. One of the best physiologic models of beta cell compensation comes from generation of peripheral insulin resistance through targeted deletion of insulin signaling components in mice. IRS1 knockout mice have increased insulin requirement due to peripheral resistance, and to compensate develop a markedly increased beta cell mass $[79,80]$. Insulin secretion remains adequate, and the mice do not become diabetic. Mice lacking IRS2, on the other hand, have a quite different phenotype [51, 79, 81]. Peripheral insulin resistance is increased like in the IRS1 knockout mouse, but beta cells are unable to effectively compensate. Beta cell proliferation is reduced, beta cell mass declines, and the mice become diabetic. In a different strain, a similar but milder phenotype was observed [82]. Thus, IRS2 appears to be essential for beta cell compensation for increased insulin demand due to peripheral insulin resistance. Conversely, increased IRS2 expression promotes beta cell replication and prevents diabetes [83, 84]. Remarkably, even mice lacking only one allele of IRS2, with one normal allele present, have reduced beta cell compensatory reserve. IRS2+/- mice have normal body weight, blood glucose, beta cell mass and plasma insulin [79-81, 85]. However, glucose tolerance worsens in IRS2+/mice that have only one allele of IGF1R [81] or Pdx1 [85] compared to the glucose tolerance in IRS2 $+/+$ mice that are IGF1R+/- or Pdx1+/-. Thus, the presence of both alleles of IRS2 in Pdx1 or IGF1R haploinsufficient mice is necessary to preserve their glucose tolerance. Recent studies by Kulkarni's group have shown that beta cells from IR or IRS2 knockout mice display reduced DNA synthesis in response to glucose stimulation in vitro [20]. Intriguingly, in insulinoma cells overexpressing IRS2, glucose (15 $\mathrm{mM}$ vs 3 


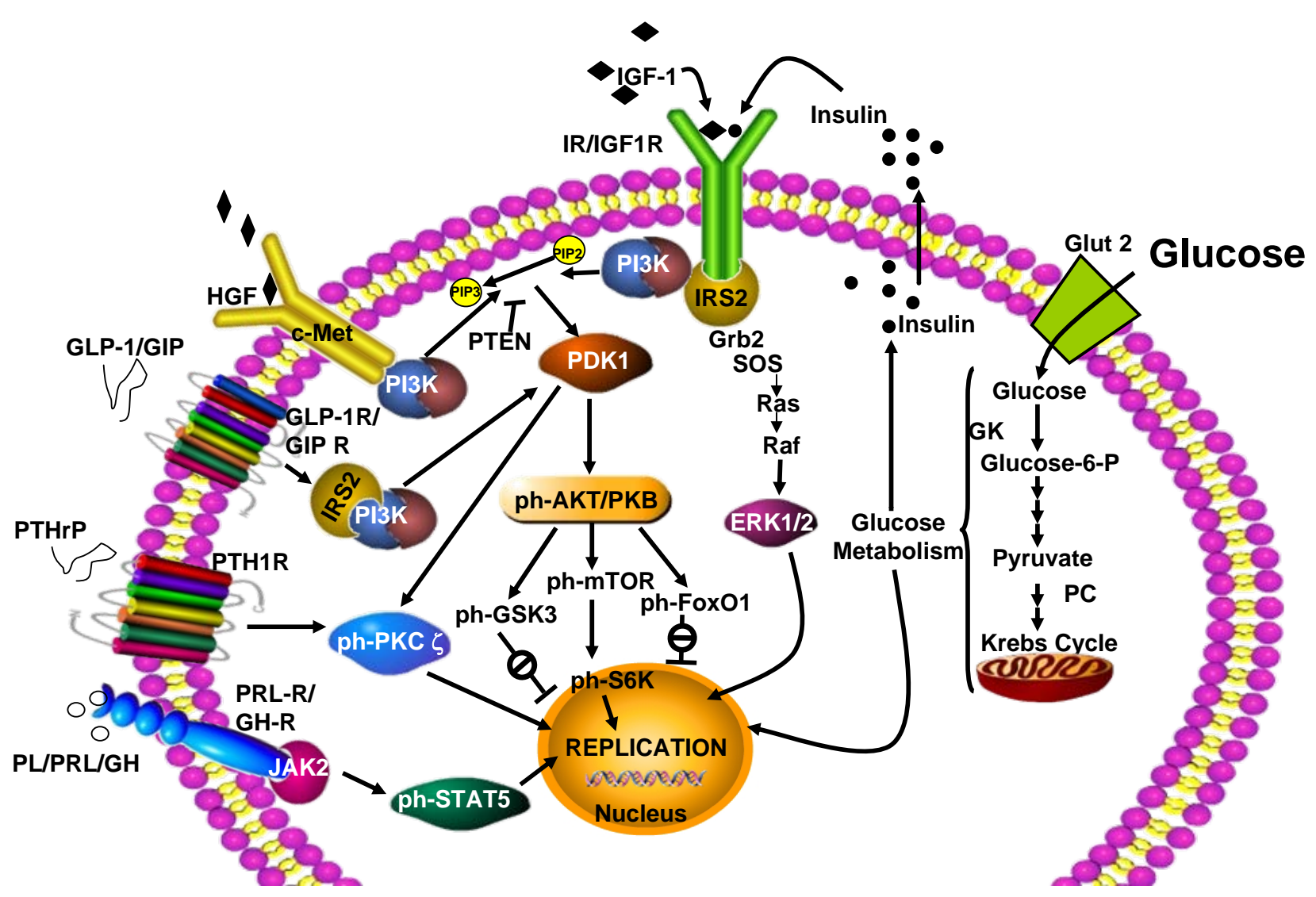

Fig. (2). Schematic representation of the signaling elements involved in glucose-mediated beta cell proliferation in vitro. Since intracellular pathways downstream of the insulin receptor (IR) and IGF1-R are similar, only one receptor is depicted here. Similarly, one receptor is depicted for lactogenic hormones placental lactogen (PL), prolactin (PRL), and growth hormone $(\mathrm{GH})$. ph=phosphorylated; PTEN=phosphatase and tensin homolog; PDK1=phosphoinositide-dependent kinase 1; PIP2=Phosphatidylinositol (4,5)-bisphosphate; PIP3=Phosphatidylinositol (3,4,5)-triphosphate; Grb2=growth factor receptor-bound protein 2; SOS=Son of Sevenless; $\boldsymbol{\Theta}=$ blockade of inhibitory action.

$\mathrm{mM}$ ) stimulation of beta cell proliferation is synergistic with IRS2 [71]. Taken together, these studies highlight a potential key role of IRS2 in glucose-induced beta cell proliferation in vivo.

Inhibition of PI3K with wortmannin blocks glucosemediated INS-1 cell proliferation, suggesting a role for PI3K in beta cell proliferation induced by $15 \mathrm{mM}$ glucose [11]. Studies also suggested that there is a requirement for activation of both ERK1/ERK2 and mTOR/p70S6K signaling pathways for a full commitment to $15 \mathrm{mM}$ glucose-induced pancreatic beta cell mitogenesis $[11,71]$. In this regard, McDaniel's group has shown that inhibition of mTOR with rapamycin blocks glucose-stimulated DNA synthesis in rat islets $(25 \mathrm{mM}$ vs $3 \mathrm{mM})$ [77]. More recently the same group has reported that a combination of glycogen synthase kinase-3 (GSK-3) inhibition and glucose activation of mTOR ( $8 \mathrm{mM}$ vs $5 \mathrm{mM}$ ) contributes to enhanced DNA synthesis, cell cycle progression, and proliferation of human beta-cells [78]. Glucose- and growth factor-mediated inactivation of FoxO transcription factors, which are PI3K/AKT targets, leads to downregulation of the transcriptional repressor BCL-6 and increased cyclin D2 expression and beta cell proliferation, implicating FoxO as a key mediator in glucose-induced beta cell replication [21].

In summary, while it is known that glucose acts in the beta cell to promote insulin secretion and to generate important signals which help to regulate gene expression and protein synthesis, the precise involvement of the insulin signaling pathway in glucose-mediated beta cell proliferation in vivo is unknown. Of note, insulin signaling has also been shown to increase glucose sensing in the beta cell, through upregulation of Glut2 and glucokinase expression [86, 87]. Chronic glucose infusion experiments in IRS2+/- mice might be an interesting model to test for IRS2 involvement in glucose-induced beta cell compensatory mechanisms, because these mice are metabolically normal at baseline but decompensate if challenged.

\section{Glucose Metabolic Pathways}

Glucokinase (GK) phosphorylates glucose to form glucose 6-phosphate and is the glucose sensor that regulates insulin secretion in beta cells [88]. Haploinsufficiency of beta cell-specific GK $(\mathrm{GK}+/-)$ causes impaired insulin secretion to glucose, although the animals have a normal beta cell mass [89]. When fed a high-fat (HF) diet, $\mathrm{GK}+/-$ 
mice display decreased beta cell replication and insufficient beta cell hyperplasia despite having a normal degree of insulin resistance. Islets from $\mathrm{HF}$ diet-fed $\mathrm{GK}+/$ - mice display reduced expression of IRS2 compared with those of HF diet-fed wild-type mice. Overexpression of IRS2 in beta cells of HF diet-fed $\mathrm{GK}+/$ - mice partially prevented diabetes by increasing beta cell mass. These results suggest that GK is critical for beta cell hyperplasia in response to insulin resistance. More recently, the effect of various GK activators (Compound A, GKA50 and LY2121260) (GKA) that trigger GK via binding to an allosteric site of the enzyme have been tested for their capacity to induce beta cell proliferation in vitro and in vivo [90, 91]. GKA was able to increase both beta cell replication and beta cell number in vitro in INS-1 cells. Furthermore, 3-day administration of GKA in mice also enhances beta cell replication [91]. However, chronic GKA administration failed to cause a further increase in $\beta$ cell mass in vivo. The authors suggest that a chronic reduction in ambient blood glucose levels by GKA treatment could be responsible for this absence of chronic effects. However, the studies in vitro demonstrating an effect in INS1 cells were performed at $3 \mathrm{mM}$ glucose. The authors did not test higher glucose concentrations to determine whether the effect could be amplified by a further increase in glucose phosphorylation. Finally, GK activators also induced a concomitant upregulation of IRS2 and activation of Akt/PKB phosphorylation.

In type 2 diabetes, the failure of beta cell adaptation coincides with reduced activities of pyruvate carboxylase (PC) and pyruvate dehydrogenase (PDH), two enzymes required for pyruvate conversion to the Krebs cycle intermediates oxaloacetate and acetyl-CoA, respectively [9295]. The PC inhibitor phenylacetic acid reduces beta cell proliferation in $60 \%$ pancreatectomized rats and in Zucker fatty rats, indicating the importance of this enzyme in the adaptive beta cell response to both insulin resistance and diminished beta cell mass in vivo $[37,96]$. Downregulation of PC with siRNA decreases DNA synthesis in INS-1 cells [97]. On the other hand, overexpression of PC resulted in increased INS-1 cell replication. Taken together, these studies suggest that glucose metabolism by both glycolysis and the Krebs cycle is necessary for glucose-mediated beta cell proliferation, at least in vitro.

\section{Glucose as a Facilitator of Growth Factor-Mediated Beta Cell Proliferation}

Glucose has also been shown to increase beta cell proliferation indirectly through synergistic actions with growth factors. Glucose (range, 0-24 mM) enhances rodent beta cell replication induced by insulin-like growth factor-I (IGF-I) through a mechanism facilitated by ERK1/2 activation and dependent on IRS2/PI3K/p70S6 kinase intracellular pathway induction [11]. Similar synergistic effects on beta cell proliferation and immediate-early response genes coding for transcription factors involved in beta cell replication such as c-fos, JunB, nur-268 have been observed in the combination of glucose (range, $2.5-25 \mathrm{mM}$ ) and the gluco-incretin peptides glucose-dependent insulinotropic polypeptide (GIP) and glucagon-like peptide I (GLP-1) $[98,99]$. A potential role for $\mathrm{Ca} 2+$ and IRS2/PI3K signaling pathways are suggested in these cases. Another important set of hormones that display synergistic effects with glucose on beta cell proliferation are the lactogen hormones [100-102]. Growth hormone (GH) and prolactin (PRL) stimulate beta cell proliferation through activation of the Janus kinase 2 (JAK2)/signal transducer and activator of transcription 5 (STAT 5). Glucose (15 mM) does not activate JAK2/STAT 5 and the synergistic effect of glucose and GH on beta cell proliferation does not appear to involve crosstalk among the signaling pathways. On the other hand, hepatocyte growth factor (HGF) and parathyroid-hormone related protein (PTHrP), two well known beta cell mitogens, do not display synergistic or additive effects with glucose (range, $0-24 \mathrm{mM}$ ) suggesting potential similar intracellular targets for inducing their mitogenic effects [10,22].

\section{Effect of FFA in Glucose-Mediated Beta Cell Proliferation}

In conditions of insulin resistance, such as obesity, an increased demand for insulin is compensated by an increase in insulin production and an enhancement in beta cell mass. However, when beta cell mass does not increase as a compensation for insulin resistance, obesity-linked type 2 diabetes develops. In addition to genetic susceptibilities implicated in the pathogenesis of type 2 diabetes, the mechanisms involved in beta cell failure are unknown. It is postulated that prolonged hyperglycemia and hyperlipidemia are contributing factors detrimental to beta cell mass and function [103, 104]. In vitro studies by the Rhodes group have clearly established that long-chain FFA inhibit glucosemediated ( $3 \mathrm{mM} v s 15 \mathrm{mM})$ and glucose-dependent IGF-1 induced beta cell DNA synthesis $[105,106]$. This is in part due to interference in IRS2-mediated signaling pathway and activation of novel protein kinase $\mathrm{C}$ (PKC) such as PKC $\delta$. Mice expressing a kinase-dead PKC $\delta$ isoform in beta cells are protected from HF diet-induced beta cell failure and display enhanced islet size in this setting [107]. Taken together these results suggest that FFA might limit beta cell replication and expansion in vivo, and increase peripheral insulin resistance that would contribute to beta cell compensatory failure and type 2 diabetes.

\section{CONCLUSIONS}

Physiologically speaking, glucose is a logical regulator of beta cell replication. Since a primary function of the beta cell is to lower blood glucose levels through insulin secretion, elevated blood glucose is an indicator of insufficient insulin and need for more insulin secretory capacity. The beta cell is also exquisitely sensitive to glucose concentrations, and is thus equipped to respond to small changes in glucose. To summarize decades of work in a few sentences, beta cells across widely varying species, from toad to rodent, gerbil to human, replicate in response to elevated glucose in vitro and in vivo. In vivo, the replication response to glucose is observable starting after several days' exposure to high glucose, and lasting for several weeks. Prolonged hyperglycemia results in toxicity and lower beta cell replication rate; however, restoration of normoglycemia for a period of time allows recovery of glucose stimulated replication upon re-challenge. Data in vivo in human beta cells is sparse. Mechanistically, insulin signaling pathway members such as PI3K and downstream molecules seem critically important; a direct role for secreted insulin is still debated. Glucose metabolism in the beta cell may also play a 
role, and glucose signaling also interacts with other growth factor signaling pathways in the beta cell. In summary, although much has been learned, this remains a rich territory for understanding the biology of diabetes as well as finding new therapeutic approaches to achieve beta cell regeneration.

\section{ACKNOWLEDGEMENTS}

This work was supported by grants from the National Institutes of Health to LCA (DK076562) and to AG-O (DK067351 and DK077096), the Juvenile Diabetes Research Foundation to LCA and AG-O (5-2008-189) and to A.G-O (1-2007-3), a pilot and feasibility award from the Obesity and Nutrition Research Center at the University of Pittsburgh to LCA (DK046204), and a Junior Scholar Award from the Department of Medicine at the University of Pittsburgh to LCA. We are grateful to Dr. Christopher P. O'Donnell for his contribution to this work.

\section{REFERENCES}

[1] Teta M, Long SY, Wartschow LM, Rankin MM, Kushner JA. Very slow turnover of beta-cells in aged adult mice. Diabetes 2005; 54(9): 2557-67.

[2] Sorenson RL, Brelje TC. Adaptation of islets of Langerhans to pregnancy: beta-cell growth, enhanced insulin secretion and the role of lactogenic hormones. Horm Metab Res 1997; 29(6): 301-7.

[3] Montana E, Bonner-Weir S, Weir GC. Transplanted beta-cell replication and mass increase after $95 \%$ pancreatectomy. Transplant Proc 1994; 26(2): 657.

[4] Montana E, Bonner-Weir S, Weir GC. Transplanted beta cell response to increased metabolic demand. Changes in beta cell replication and mass. J Clin Invest 1994; 93(4): 1577-82.

[5] Sachdeva MM, Stoffers DA. Minireview: Meeting the demand for insulin: molecular mechanisms of adaptive postnatal beta-cell mass expansion. Mol Endocrinol 2009; 23(6): 747-58.

[6] Butler AE, Janson J, Bonner-Weir S, Ritzel R, Rizza RA, Butler PC. Beta-cell deficit and increased beta-cell apoptosis in humans with type 2 diabetes. Diabetes 2003; 52(1): 102-10.

[7] Yoon KH, Ko SH, Cho JH, et al. Selective beta-cell loss and alphacell expansion in patients with type 2 diabetes mellitus in Korea. J Clin Endocrinol Metab 2003; 88(5): 2300-8.

[8] Henquin JC, Ravier MA, Nenquin M, Jonas JC, Gilon P. Hierarchy of the beta-cell signals controlling insulin secretion. Eur J Clin Invest 2003; 33(9): 742-50.

[9] Swenne I. The role of glucose in the in vitro regulation of cell cycle kinetics and proliferation of fetal pancreatic B-cells. Diabetes 1982; 31(9): 754-60

[10] Gahr S, Merger M, Bollheimer LC, Hammerschmied CG, Scholmerich J, Hugl SR. Hepatocyte growth factor stimulates proliferation of pancreatic beta-cells particularly in the presence of subphysiological glucose concentrations. J Mol Endocrinol 2002; 28(2): 99-110.

[11] Hugl SR, White MF, Rhodes CJ. Insulin-like growth factor I (IGFI)-stimulated pancreatic beta-cell growth is glucose-dependent. Synergistic activation of insulin receptor substrate-mediated signal transduction pathways by glucose and IGF-I in INS-1 cells. J Biol Chem 1998; 273(28): 17771-9.

[12] De Vroede MA, In' t Veld PA, Pipeleers DG. Deoxyribonucleic acid synthesis in cultured adult rat pancreatic $B$ cells. Endocrinology 1990; 127(3): 1510-6.

[13] Kaung HC. Effect of glucose on beta cell proliferation and population size in organ culture of foetal and neonatal rat pancreases. J Embryol Exp Morphol 1983; 75: 303-12.

[14] Maedler K, Schumann DM, Schulthess F, et al. Aging correlates with decreased beta-cell proliferative capacity and enhanced sensitivity to apoptosis: a potential role for Fas and pancreatic duodenal homeobox-1. Diabetes 2006; 55(9): 2455-62.

[15] Swenne I. Effects of aging on the regenerative capacity of the pancreatic B-cell of the rat. Diabetes 1983; 32(1): 14-9.

[16] Swenne I. Glucose-stimulated DNA replication of the pancreatic islets during the development of the rat fetus. Effects of nutrients, growth hormone, and triiodothyronine. Diabetes 1985; 34(8): 8037 .
[17] Swenne I, Bone AJ, Howell SL, Hellerstrom C. Effects of glucose and amino acids on the biosynthesis of DNA and insulin in fetal rat islets maintained in tissue culture. Diabetes 1980; 29(9): 686-92.

[18] Cozar-Castellano I, Harb G, Selk K, et al. Lessons from the first comprehensive molecular characterization of cell cycle control in rodent insulinoma cell lines. Diabetes 2008; 57(11): 3056-68.

[19] Scharfmann R, Basmaciogullari A, Czernichow P. Effect of growth hormone and glucose on rat islet cells replication using 5-bromo-2deoxyuridine incorporation. Diabetes Res 1990; 15(3): 137-41.

[20] Assmann A, Ueki K, Winnay JN, Kadowaki T, Kulkarni RN. Glucose effects on beta-cell growth and survival require activation of insulin receptors and insulin receptor substrate 2. Mol Cell Biol 2009; 29(11): 3219-28.

[21] Glauser DA, Schlegel W. The FoxO/Bcl-6/cyclin D2 pathway mediates metabolic and growth factor stimulation of proliferation in Min6 pancreatic beta-cells. J Recept Signal Transduct Res 2009; 29(6): 293-8.

[22] Vasavada RC, Wang L, Fujinaka Y, et al. Protein kinase C-zeta activation markedly enhances beta-cell proliferation: an essential role in growth factor mediated beta-cell mitogenesis. Diabetes 2007; 56(11): 2732-43.

[23] Guillemain G, Filhoulaud G, Da Silva-Xavier G, Rutter GA, Scharfmann R. Glucose is necessary for embryonic pancreatic endocrine cell differentiation. J Biol Chem 2007; 282(20): 1522837.

[24] Tyrberg B, Eizirik DL, Hellerstrom C, Pipeleers DG, Andersson A. Human pancreatic beta-cell deoxyribonucleic acid-synthesis in islet grafts decreases with increasing organ donor age but increases in response to glucose stimulation in vitro. Endocrinology 1996; 137(12): 5694-9.

[25] Maedler K, Oberholzer J, Bucher P, Spinas GA, Donath MY. Monounsaturated fatty acids prevent the deleterious effects of palmitate and high glucose on human pancreatic beta-cell turnover and function. Diabetes 2003; 52(3): 726-33.

[26] Maedler K, Sergeev P, Ris F, et al. Glucose-induced beta cell production of IL-1beta contributes to glucotoxicity in human pancreatic islets. J Clin Invest 2002; 110(6): 851-60.

[27] Del Zotto H, Gomez Dumm CL, Drago S, Fortino A, Luna GC, Gagliardino JJ. Mechanisms involved in the beta-cell mass increase induced by chronic sucrose feeding to normal rats. J Endocrinol 2002; 174(2): 225-31.

[28] Del Zotto H, Massa L, Gomez Dumm CL, Gagliardino JJ. Changes induced by sucrose administration upon the morphology and function of pancreatic islets in the normal hamster. Diabetes Metab Res Rev 1999; 15(2): 106-12.

[29] Kaiser N, Yuli M, Uckaya G, et al. Dynamic changes in \{beta\}-cell mass and pancreatic insulin during the evolution of nutritiondependent diabetes in psammomys obesus: impact of glycemic control. Diabetes 2005; 54(1): 138-45

[30] Koiter TR, Wijkstra S, van Der Schaaf-Verdonk CJ, Moes H, Schuiling GA. Pancreatic beta-cell function and islet-cell proliferation: effect of hyperinsulinaemia. Physiol Behav 1995; 57(4): 717-21

[31] Lee HC, Bonner-Weir S, Weir GC, Leahy JL. Compensatory adaption to partial pancreatectomy in the rat. Endocrinology 1989; 124(3): 1571-5.

[32] Leahy JL, Weir GC. Beta-cell dysfunction in hyperglycaemic rat models: recovery of glucose-induced insulin secretion with lowering of the ambient glucose level. Diabetologia 1991; 34(9): 640-7.

[33] Bonner-Weir S, Trent DF, Weir GC. Partial pancreatectomy in the rat and subsequent defect in glucose-induced insulin release. J Clin Invest 1983; 71(6): 1544-53.

[34] Liu YQ, Nevin PW, Leahy JL. beta-cell adaptation in $60 \%$ pancreatectomy rats that preserves normoinsulinemia and normoglycemia. Am J Physiol Endocrinol Metab 2000; 279(1): E68-73.

[35] Leahy JL, Bonner-Weir S, Weir GC. Minimal chronic hyperglycemia is a critical determinant of impaired insulin secretion after an incomplete pancreatectomy. J Clin Invest 1988; 81(5): 1407-14.

[36] Liu YQ, Montanya E, Leahy JL. Increased islet DNA synthesis and glucose-derived lipid and amino acid production in association with beta-cell hyperproliferation in normoglycaemic $60 \%$ pancreatectomy rats. Diabetologia 2001; 44(8): 1026-33. 
[37] Liu YQ, Han J, Epstein PN, Long YS. Enhanced rat beta-cell proliferation in $60 \%$ pancreatectomized islets by increased glucose metabolic flux through pyruvate carboxylase pathway. Am J Physiol Endocrinol Metab 2005; 288(3): E471-8.

[38] Woerner C. Studies of the Islands of Langerhans after continuous intravenous injection of dextrose. Anat Rec 1938; 71(1): 33-57.

[39] Francini F, Del Zotto H, Gagliardino JJ. Effect of an acute glucose overload on Islet cell morphology and secretory function in the toad. Gen Comp Endocrinol 2001; 122(2): 130-8.

[40] Bonner-Weir S, Deery D, Leahy JL, Weir GC. Compensatory growth of pancreatic beta-cells in adult rats after short-term glucose infusion. Diabetes 1989; 38(1): 49-53.

[41] Steil GM, Trivedi N, Jonas JC, et al. Adaptation of beta-cell mass to substrate oversupply: enhanced function with normal gene expression. Am J Physiol Endocrinol Metab 2001; 280(5): E78896.

[42] Jetton TL, Everill B, Lausier J, et al. Enhanced beta-cell mass without increased proliferation following chronic mild glucose infusion. Am J Physiol Endocrinol Metab 2008; 294(4): E679-87.

[43] Topp BG, McArthur MD, Finegood DT. Metabolic adaptations to chronic glucose infusion in rats. Diabetologia 2004; 47(9): 160210 .

[44] Paris M, Bernard-Kargar C, Berthault MF, Bouwens L, Ktorza A. Specific and combined effects of insulin and glucose on functional pancreatic beta-cell mass in vivo in adult rats. Endocrinology 2003; 144(6): 2717-27.

[45] Bernard C, Berthault MF, Saulnier C, Ktorza A. Neogenesis vs apoptosis As main components of pancreatic beta cell ass changes in glucose-infused normal and mildly diabetic adult rats. FASEB J 1999; 13(10): 1195-205.

[46] Bernard C, Thibault C, Berthault MF, et al. Pancreatic beta-cell regeneration after 48 - $\mathrm{h}$ glucose infusion in mildly diabetic rats is not correlated with functional improvement. Diabetes 1998; 47(7): 1058-65.

[47] Kuboi M, Egawa M, Udaka N, Ito T, Inoue S, Sekihara H. Effects of a 7-day infusion of glucose on insulin secretion in vivo and in vitro in ventromedial hypothalamic-lesioned obese rats. Acta Diabetol 1998; 35(1): 26-33.

[48] Hagman DK, Latour MG, Chakrabarti SK, et al. Cyclical and alternating infusions of glucose and intralipid in rats inhibit insulin gene expression and Pdx-1 binding in islets. Diabetes 2008; 57(2): 424-31.

[49] Jonas JC, Laybutt DR, Steil GM, et al. High glucose stimulates early response gene c-Myc expression in rat pancreatic beta cells. J Biol Chem 2001; 276(38): 35375-81.

[50] Alonso LC, Yokoe T, Zhang P, et al. Glucose infusion in mice: a new model to induce beta-cell replication. Diabetes 2007; 56(7): 1792-801

[51] Bruning JC, Winnay J, Bonner-Weir S, Taylor SI, Accili D, Kahn CR. Development of a novel polygenic model of NIDDM in mice heterozygous for IR and IRS-1 null alleles. Cell 1997; 88(4): 56172.

[52] Laury MC, Penicaud L, Ktorza A, Benhaiem H, Bihoreau MT, Picon L. In vivo insulin secretion and action in hyperglycemic rat. Am J Physiol 1989; 257(2 Pt 1): E180-4.

[53] Montana E, Bonner-Weir S, Weir GC. Beta cell mass and growth after syngeneic islet cell transplantation in normal and streptozocin diabetic C57BL/6 mice. J Clin Invest 1993; 91(3): 780-7.

[54] Merino JF, Nacher V, Raurell M, Aranda O, Soler J, Montanya E. Improved outcome of islet transplantation in insulin-treated diabetic mice: effects on beta-cell mass and function. Diabetologia 1997; 40(9): 1004-10.

[55] Juang JH, Bonner-Weir S, Wu YJ, Weir GC. Beneficial influence of glycemic control upon the growth and function of transplanted islets. Diabetes 1994; 43(11): 1334-9.

[56] Nacher V, Merino JF, Raurell M, Soler J, Montanya E. Normoglycemia restores beta-cell replicative response to glucose in transplanted islets exposed to chronic hyperglycemia. Diabetes 1998; 47(2): 192-6.

[57] Biarnes M, Montolio M, Nacher V, Raurell M, Soler J, Montanya E. Beta-cell death and mass in syngeneically transplanted islets exposed to short- and long-term hyperglycemia. Diabetes 2002; 51(1): 66-72.

[58] Chen X, Zhang X, Chen F, Larson CS, Wang LJ, Kaufman DB. Comparative study of regenerative potential of beta cells from young and aged donor mice using a novel islet transplantation model. Transplantation 2009; 88(4): 496-503.

[59] Tuttle RL, Gill NS, Pugh W, et al. Regulation of pancreatic betacell growth and survival by the serine/threonine protein kinase Akt1/PKBalpha. Nat Med 2001; 7(10): 1133-7.

[60] Pechhold K, Koczwara K, Zhu X, et al. Blood glucose levels regulate pancreatic beta-cell proliferation during experimentallyinduced and spontaneous autoimmune diabetes in mice. PLoS One 2009; 4(3): e4827.

[61] Edvell A, Lindstrom P. Initiation of increased pancreatic islet growth in young normoglycemic mice (Umea $+/$ ?). Endocrinology 1999; 140(2): 778-83.

[62] Chick WL, Like AA. Studies in the diabetic mutant mouse. 3. Physiological factors associated with alterations in beta cell proliferation. Diabetologia 1970; 6(3): 243-51.

[63] Butler PC, Meier JJ, Butler AE, Bhushan A. The replication of beta cells in normal physiology, in disease and for therapy. Nat Clin Pract Endocrinol Metab 2007; 3(11): 758-68.

[64] Meier JJ, Lin JC, Butler AE, Galasso R, Martinez DS, Butler PC. Direct evidence of attempted beta cell regeneration in an 89-yearold patient with recent-onset type 1 diabetes. Diabetologia 2006; 49(8): 1838-44.

[65] Meier JJ, Bhushan A, Butler AE, Rizza RA, Butler PC. Sustained beta cell apoptosis in patients with long-standing type 1 diabetes: indirect evidence for islet regeneration? Diabetologia 2005; 48(11): 2221-8

[66] Robertson RP, Lanz KJ, Sutherland DE, Seaquist ER. Relationship between diabetes and obesity 9 to 18 years after hemipancreatectomy and transplantation in donors and recipients. Transplantation 2002; 73(5): 736-41.

[67] Menge BA, Tannapfel A, Belyaev O, et al. Partial pancreatectomy in adult humans does not provoke beta-cell regeneration. Diabetes 2008; 57(1): 142-9.

[68] Movassat J, Saulnier C, Portha B. Insulin administration enhances growth of the beta-cell mass in streptozotocin-treated newborn rats. Diabetes 1997; 46(9): 1445-52.

[69] Rabinovitch A, Quigley C, Russell T, Patel Y, Mintz DH. Insulin and multiplication stimulating activity (an insulin-like growth factor) stimulate islet (beta-cell replication in neonatal rat pancreatic monolayer cultures. Diabetes 1982; 31(2): 160-4

[70] Kulkarni RN, Bruning JC, Winnay JN, Postic C, Magnuson MA, Kahn CR. Tissue-specific knockout of the insulin receptor in pancreatic beta cells creates an insulin secretory defect similar to that in type 2 diabetes. Cell 1999; 96(3): 329-39.

[71] Lingohr MK, Dickson LM, McCuaig JF, Hugl SR, Twardzik DR, Rhodes CJ. Activation of IRS-2-mediated signal transduction by IGF-1, but not TGF-alpha or EGF, augments pancreatic beta-cell proliferation. Diabetes 2002; 51(4): 966-76.

[72] Ohsugi M, Cras-Meneur C, Zhou Y, et al. Reduced expression of the insulin receptor in mouse insulinoma (MIN6) cells reveals multiple roles of insulin signaling in gene expression, proliferation, insulin content, and secretion. J Biol Chem 2005; 280(6): $4992-$ 5003

[73] Srinivasan S, Bernal-Mizrachi E, Ohsugi M, Permutt MA. Glucose promotes pancreatic islet beta-cell survival through a PI 3kinase/Akt-signaling pathway. Am J Physiol Endocrinol Metab 2002; 283(4): E784-93.

[74] Frodin M, Sekine N, Roche E, et al. Glucose, other secretagogues, and nerve growth factor stimulate mitogen-activated protein kinase in the insulin-secreting beta-cell line, INS-1. J Biol Chem 1995; 270(14): 7882-9.

[75] Khoo S, Cobb MH. Activation of mitogen-activating protein kinase by glucose is not required for insulin secretion. Proc Natl Acad Sci USA 1997; 94(11): 5599-604.

[76] Dickson LM, Lingohr MK, McCuaig J, et al. Differential activation of protein kinase $\mathrm{B}$ and $\mathrm{p} 70(\mathrm{~S} 6) \mathrm{K}$ by glucose and insulin-like growth factor 1 in pancreatic beta-cells (INS-1). J Biol Chem 2001; 276(24): 21110-20.

[77] Kwon G, Marshall CA, Pappan KL, Remedi MS, McDaniel ML. Signaling elements involved in the metabolic regulation of mTOR by nutrients, incretins, and growth factors in islets. Diabetes 2004; 53(Suppl 3): S225-32.

[78] Liu H, Remedi MS, Pappan KL, et al. Glycogen synthase kinase-3 and mammalian target of rapamycin pathways contribute to DNA synthesis, cell cycle progression, and proliferation in human islets. Diabetes 2009; 58(3): 663-72. 
[79] Kido Y, Burks DJ, Withers D, et al. Tissue-specific insulin resistance in mice with mutations in the insulin receptor, IRS-1, and IRS-2. J Clin Invest 2000; 105(2): 199-205.

[80] Withers DJ, Gutierrez JS, Towery H, et al. Disruption of IRS-2 causes type 2 diabetes in mice. Nature 1998; 391(6670): 900-4.

[81] Withers DJ, Burks DJ, Towery HH, Altamuro SL, Flint CL, White MF. Irs-2 coordinates Igf-1 receptor-mediated beta-cell development and peripheral insulin signalling. Nat Genet 1999; 23(1): 32-40.

[82] Kubota N, Tobe K, Terauchi Y, et al. Disruption of insulin receptor substrate 2 causes type 2 diabetes because of liver insulin resistance and lack of compensatory beta-cell hyperplasia. Diabetes 2000; 49(11): 1880-9.

[83] Hennige AM, Burks DJ, Ozcan U, et al. Upregulation of insulin receptor substrate-2 in pancreatic beta cells prevents diabetes. J Clin Invest 2003; 112(10): 1521-32.

[84] Mohanty S, Spinas GA, Maedler K, et al. Overexpression of IRS2 in isolated pancreatic islets causes proliferation and protects human beta-cells from hyperglycemia-induced apoptosis. Exp Cell Res 2005; 303(1): 68-78.

[85] Kushner JA, Ye J, Schubert M, et al. Pdx1 restores beta cell function in Irs2 knockout mice. J Clin Invest 2002; 109(9): 1193201.

[86] Yoshida K, Murao K, Imachi H, et al. Pancreatic glucokinase is activated by insulin-like growth factor-I. Endocrinology 2007; 148(6): 2904-13.

[87] Watada H, Kajimoto Y, Umayahara Y, et al. The human glucokinase gene beta-cell-type promoter: an essential role of insulin promoter factor 1/PDX-1 in its activation in HIT-T15 cells. Diabetes 1996; 45(11): 1478-88.

[88] Matschinsky FM. Assessing the potential of glucokinase activators in diabetes therapy. Nat Rev Drug Discov 2009; 8(5): 399-416.

[89] Terauchi Y, Takamoto I, Kubota N, et al. Glucokinase and IRS-2 are required for compensatory beta cell hyperplasia in response to high-fat diet-induced insulin resistance. J Clin Invest 2007; 117(1): 246-57.

[90] Wei P, Shi M, Barnum S, Cho H, Carlson T, Fraser JD. Effects of glucokinase activators GKA50 and LY2121260 on proliferation and apoptosis in pancreatic INS-1 beta cells. Diabetologia 2009; 52(10): 2142-50.

[91] Nakamura A, Terauchi Y, Ohyama S, et al. Impact of smallmolecule glucokinase activator on glucose metabolism and betacell mass. Endocrinology 2009; 150(3): 1147-54.

[92] MacDonald MJ, Tang J, Polonsky KS. Low mitochondrial glycerol phosphate dehydrogenase and pyruvate carboxylase in pancreatic islets of Zucker diabetic fatty rats. Diabetes 1996; 45(11): 1626-30.

[93] MacDonald MJ, Efendic S, Ostenson CG. Normalization by insulin treatment of low mitochondrial glycerol phosphate dehydrogenase and pyruvate carboxylase in pancreatic islets of the GK rat. Diabetes 1996; 45(7): 886-90.

[94] Zhou YP, Berggren PO, Grill V. A fatty acid-induced decrease in pyruvate dehydrogenase activity is an important determinant of beta-cell dysfunction in the obese diabetic $\mathrm{db} / \mathrm{db}$ mouse. Diabetes 1996; 45(5): 580-6.
[95] Zhou YP, Ostenson CG, Ling ZC, Grill V. Deficiency of pyruvate dehydrogenase activity in pancreatic islets of diabetic GK rats. Endocrinology 1995; 136(8): 3546-51.

[96] Liu YQ, Jetton TL, Leahy JL. beta-Cell adaptation to insulin resistance. Increased pyruvate carboxylase and malate-pyruvate shuttle activity in islets of nondiabetic Zucker fatty rats. J Biol Chem 2002; 277(42): 39163-8.

[97] Xu J, Han J, Long YS, Epstein PN, Liu YQ. The role of pyruvate carboxylase in insulin secretion and proliferation in rat pancreatic beta cells. Diabetologia 2008; 51(11): 2022-30.

[98] Susini S, Roche E, Prentki M, Schlegel W. Glucose and glucoincretin peptides synergize to induce c-fos, c-jun, junB, zif268, and nur-77 gene expression in pancreatic beta(INS-1) cells. FASEB J 1998; 12(12): 1173-82.

[99] Trumper A, Trumper K, Trusheim H, Arnold R, Goke B, Horsch D. Glucose-dependent insulinotropic polypeptide is a growth factor for beta (INS-1) cells by pleiotropic signaling. Mol Endocrinol 2001; 15(9): 1559-70.

[100] Brelje TC, Scharp DW, Lacy PE, et al. Effect of homologous placental lactogens, prolactins, and growth hormones on islet B-cell division and insulin secretion in rat, mouse, and human islets: implication for placental lactogen regulation of islet function during pregnancy. Endocrinology 1993; 132(2): 879-87.

[101] Cousin SP, Hugl SR, Myers MG, Jr., White MF, Reifel-Miller A, Rhodes CJ. Stimulation of pancreatic beta-cell proliferation by growth hormone is glucose-dependent: signal transduction via janus kinase 2 (JAK2)/signal transducer and activator of transcription 5 (STAT5) with no crosstalk to insulin receptor substrate-mediated mitogenic signalling. Biochem J 1999; 344(Pt 3): $649-58$

[102] Stout LE, Svensson AM, Sorenson RL. Prolactin regulation of islet-derived INS-1 cells: characteristics and immunocytochemical analysis of STAT5 translocation. Endocrinology 1997; 138(4): 1592-603.

[103] Poitout V, Robertson RP. Glucolipotoxicity: fuel excess and betacell dysfunction. Endocr Rev 2008; 29(3): 351-66.

[104] Chang-Chen KJ, Mullur R, Bernal-Mizrachi E. Beta-cell failure as a complication of diabetes. Rev Endocr Metab Disord 2008; 9(4): 329-43.

[105] Cousin SP, Hugl SR, Wrede CE, Kajio H, Myers MG, Jr., Rhodes CJ. Free fatty acid-induced inhibition of glucose and insulin-like growth factor I-induced deoxyribonucleic acid synthesis in the pancreatic beta-cell line INS-1. Endocrinology 2001; 142(1): 22940.

[106] Wrede CE, Dickson LM, Lingohr MK, Briaud I, Rhodes CJ. Fatty acid and phorbol ester-mediated interference of mitogenic signaling via novel protein kinase $\mathrm{C}$ isoforms in pancreatic beta-cells (INS1). J Mol Endocrinol 2003; 30(3): 271-86.

[107] Hennige AM, Ranta F, Heinzelmann I, et al. Overexpression of kinase-negative protein kinase Cdelta in pancreatic beta-cells protects mice from diet-induced glucose intolerance and beta-cell dysfunction. Diabetes 2010; 59(1): 119-27. 